\title{
60S Ribosomal Protein L10
}

National Cancer Institute

\section{Source}

National Cancer Institute. 60S Ribosomal Protein L10. NCI Thesaurus. Code C29882.

$60 S$ ribosomal protein $\mathrm{L} 10(214 \mathrm{aa}, \sim 25 \mathrm{kDa})$ is encoded by the human RPL10 gene. This protein plays a role in the function and structure of the large ribosomal subunit. 